\title{
Sustainable development: a narcissistic strategy to cope with the environmental crisis?
}

\author{
Adriano Kasiorowski de Araujo \\ Gabriela Marques Di Giulio
}

${ }^{1}$ School of Public Health University of São Paulo, Brazil

School of Public Health University of São Paulo, Brazil

\begin{abstract}
This article analyzes the institutionalization of the discourse of sustainable development (SD) for more than three decades and its development as a symbolic structure that influences subjectivity and social practices in this century. Embracing an interdisciplinary approach, it focuses on a debate between psychoanalysis, attentive to the ways in wich discontent is manifested, and the ideas of risk society and reflexive modernization, from social risk theory. The analysis of the SD discourse allows to frame it as a narcissistic strategy to cope with the environmental crisis. Such a strategy structures itself in the very preservation of existence at the same time that it disputes a constant process of defining which way of life populations should live and how human conduct should be guided. As a discourse that denies finitude, supported by the need for efficiency and technological development in order to avoid the end of resources, this narcissistic strategy may ultimately lay the foundation of human and environmental exhaustion.
\end{abstract}

Keywords: Narcissism, survival, risk, reflexivity, sustainable development.

São Paulo. Vol. 23, 2020

Original Article

DOI: http://dx.doi.org/10.1590/1809-4422asoc20190050r3vu2020L6AO 


\section{Introduction}

In 2019 the United Nations (UN) published the report Global Environment Outlook Six (GEO 6, 2019), a technical-political document that assessed the global state of public policies in different nations to reach the Sustainable Development Goals (SDGs). Four years before, in 2015, the UN had launched the 2030 Agenda, whose title was Transforming Our World, a document that establishes 17 SDGs, with 60 goals and more than 200 indicators. This was an elaboration and an enhancement of the Millennium Development Goals (MDGs) of 2000 (UN, 2015).

The first decade of the twenty-first century also involved a significant scientific effort to understand and, to an extent, manage the effects caused by climate change and environmental problems. In 2009, for example, a study gained prominence by foregrounding planetary thresholds: acidification of the oceans, global warming, ozone depletion, erosion of biodiversity, excessive loads of nitrogen and phosphorus, water insecurity, chemical pollution and irresponsible land uses (ROCKSTRÖM et al., 2009). As evidenced by the publication, these thresholds continued to be threatened even though, since 1992 - when the most important conference on development and the environment was held (CNUMAD, 1992), prompting the inclusion of this debate on the agenda of different governments - there has been a political-institutional effort to establish international treaties on desertification, climate change and biodiversity loss.

In this article, we argue that the consolidation of this global concern about the environment is closely related to the publication of the Brundtland Report or Our Common Future. Such concern permeates scientific production, governments and social institutions and has penetrated the daily lives of populations as a common problem for humanity in an increasingly present and urgent way. The document, produced by the World Commission on Environment and Development (CMMAD, 1987), institutionalized a key concept under which this global concern is articulated: Sustainable Development.

As described in Our Common Future, this key concept is linked to a diagnosis of a way of acting in the world which is structured by a model of development that destroys and degrades natural resources and processes. The way societies developed, especially after the industrial era (HERCULANO, 1992), produced processes that overwhelmed the Earth system, causing this path to be questioned; otherwise, the survival of humanity would be put at risk (CMMAD, 1987).

This global threat is at the origin of a narrative about another change, also global in scope, in the form of development (NASCIMENTO, 2012), which has served as a means of mobilizing the diverse nations of the globe in a common effort to change the installed paradigm. Thus, an understanding of the unsustainability of being in the world emerges from a particular, eminently destructive form of social organization in which it is made increasingly evident that the process of producing existence, in addition to producing wealth, also allows risks to existence itself to proliferate. Such risks, understood as side effects of the process of modernity, industrialization and technical-scientific development, are recognized scientifically and institutionally as global risks (BECK, 2010).

The environmental crisis, one of the most prominent global risks established at this 
moment between the twentieth and twenty-first centuries, can also be understood as an existential crisis (LAGO et al., 2013). Since the publication of the Brundtland Report, more than 30 years ago, the conceptual arrangement shaped around sustainable development has become a discourse, or a symbolic structure, that produces a social bond, as we argue from the conception of psychoanalysis. As such, its circulation in society functions as a platform for thought and action that entwines subjectivity, not as a monolithic amalgam but, above all, one constituted by a conflictual and polysemic characteristic (SILVA JÚNIOR et al., 2015).

Thus, sustainable development has become a field of political dispute and of different modalities of application by governments and civil society, who make use of its articulation according to their demands and power struggles. Its polysemy can also be seen in scientific research, which has created varied concerns. Dryzek (2005) seeks to relate some aspects of this discourse: those that focus on the survival of human and nonhuman beings; those concerned about solving environmental problems; the approach that defends the idea of conscientious and green policies; and the prospect of reconciling economic growth and environmental protection.

This article does not intend to problematize each of these concerns, but concentrates on proposing a psychoanalytical reading of Our Common Future and, more specifically, on the institutionalization of the sustainable development discourse. Its interest, therefore, centers on its institutional birth, for it is there that we may understand how this symbolic structure seeks to relate subjects, particularly in the twenty-first century. The hypothesis is that this institutionality reflects the social ideals of a moment referred to in the psychoanalytic literature as a culture of narcissism, also called survivalism (LASCH, 1983). These ideals share the same matrix as the discourse that produces contemporary psychological suffering (CRISTÓFARO et al., 2018; SAFATLE, 2018). However, from the 1980s onwards, survivalism took on a global character in environmental narratives. We argue that, at the turn of the century, this new layer began to reconfigure the symbolic structure. As a consequence, social practices and ways of being in the world were also reordered.

The objective of this article is to analyze sustainable development as a narcissistic coping strategy for the environmental crisis by framing survival as an underlying theme of this international political strategy. It is important to point out that the term narcissistic strategy is used here in the sense attributed by Lasch (1983) and Costa (2003). The former thinks of it as part of a social pathology; the latter approaches it as a defense mechanism resulting from social organization, such that it may be situated as a subjective response to crisis situations, real or imagined, and as a fundamental part of understanding discontent in a society of global risk.

Thus, this article intends to fill a gap observed in interdisciplinary analyses of environmental problems (FERREIRA, 2006) with studies that move between the human and natural sciences (DRUMMOND, 2006; SILVA JUNIOR et al., 2015): the still timid contribution of work that engages psychoanalysis to address these issues (SEARLES, 1972; RANDALL, 2009; SWYNGEDOUW, 2010; DODDS, 2012; WEINTROBE, 2013). In 
general, studies that dialogue with psychoanalysis still focus on the subject's relationship to loss, death and the grieving process in relation to the environmental crisis. However, the psychoanalytic contribution to the understanding of the environmental crisis - or existential crisis, as we call it - extends to the interpretation of culture (MEZAN, 1985).

Psychoanalysis is a science understood both as a theory and as a method of investigation (FREUD, 2006a, 2006b) in which the construction and reconstruction of the meanings of discourse are privileged (FREUD, 2006c; IRIBARRY, 2003; COSTA; POLI, 2006; ROSA, 2004). It is therefore a practice of discourse analysis that allows, as Dunker et al.(2016) note, to connect with other discourses and to deduce what they highlight through repetition, absence or denial. In this sense, psychoanalysis is positioned as a conjectural science and is attentive to the transformations of its time and the ways in which discontent is manifested (DUNKER et al., 2002). For Silva Júnior (2017), the genuinely psychoanalytic contribution to political and social analysis lies in its capacity to point out deficits in the grammar that organizes ways of being in the world.

From this perspective this article seeks to analyze sustainable development and its relationship to survivalism, based on its inscription in Our Common Future. The choice of narcissism as a theoretical resource is mainly due to the document's treatment of the environmental crisis as a planetary crisis that threatens the survival of humans and non-humans. Our focus on the subjective dimension, in light of psychoanalysis, does not dispense with concrete social relationships, but rather is interested in the unconscious dimension of these relationships (ROSA; DOMINGUES, 2010). In this sense, for the proposed analysis, we also seek to engage with conceptions from social risk theory, specifically with the ideas of "risk society" and "reflexive modernization" proposed by Beck (1995, 1999, 2002, 2006, 2010).

The article is divided into five sections, in addition to this introduction and the final considerations. In the first section, the concepts of narcissism and survival are presented. Then, we present the idea of risk from Beck's sociological perspective. In the third section, the understanding of reflexivity is explored in order to situate sustainable development. In the fourth, we discuss how this type of development can be understood as a narcissistic strategy. Finally, the fifth section discusses the potential subjective effects of the sustainable development discourse.

\section{Narcissism and survival}

Narcissism is a psychoanalytic concept that borrows the Greek myth of Narcissus - the hero who destroys himself after falling in love with his own reflected image (CANEVACCI, 1991). This passion for oneself is central to the concept's theoretical usage because narcissism is initially described as a particular mode of libidinal investment. Libido, according to psychoanalytic theory, means an energy that leaves the body for objects (NASIO, 1997).

Since its theoretical conception, narcissism has been linked to self-preservation (FREUD, 2006d). It is a characteristic intrinsic to living beings in order to stay alive; it is in their constitution, functioning as a means of protection for survival. This early phase 
of life is characterized by the indifferentiation of the Self with the world, experienced as wholeness and felt as omnipotence. It is frustration and the deferral of satisfactions that permit the loss of omnipotence, which, nevertheless, becomes a permanent absence and a space in which this lost wholeness is sought.

Two aspects are therefore relevant to the understanding of narcissism. The first concerns the search for a lost wholeness. The second concerns fragility and vulnerability in the face of absence, crisis, and loss. Narcissism may thus be understood as a constitutional part of the relationship that the subject establishes with reality, in which the subject, facing its own fragility, resorts to denial through omnipotent (even if imaginary) productions. The crisis is linked to a disintegration fantasy that triggers defenses, leading to the search for an imaginary wholeness that, nevertheless, reveals its fragility before the threat. This process is sometimes read as an anguish of annihilation or, simply translated, as a fear of death. From this process, the narratives structured around survival are derived.

In this understanding, traumatic experiences involving loss or frustration are experienced as a shattering. Crises represent collapse, in the face of which the libido is invested in objects that represent a protective measure against the anguish of disintegration. It is an unconscious process of maintaining survival, which, in the political field, facilitates identification with discourses that offer security. These discourses are based in ways of avoiding the encounter with the figures of finitude, condensed under the word crisis.

Narcissism is the psychoanalytic explanation for conduct that is directed towards self-preservation in the face of an identified threat. The threat does not have to be true for the narcissistic response to appear; it is enough to face a situation that mobilizes, through discourse, the anguish of disintegration (FREUD, 2006d).

Lasch (1983) argued that since 1960s there was a proliferation of the idea of crises and an imaginary certainty that these crises would lead to catastrophe. The author used the term "survival mentality" to describe his perception that various aspects of reality had come to be understood and confronted as matters of life and death. Exposure to successive crises in people's daily lives requires them to develop coping measures or, as he argues, "narcissistic survival strategies" (LASCH, 1986, p. 53). For the author, it is in this context that risk became part of everyday life in a widespread way: first in the form of nuclear war and then in the form of ecological catastrophe, both threats accompanied by economic collapse (LASCH, 1986, pp. 54-55). These aspects would be indicators of a type of social bond that produces uncertainty and conduces to the subject's appeal to promises of protection, albeit unconsciously.

The Frankfurt School also considered narcissism an important aspect of the analysis of this period, as Crochík (1990) acknowledges. The author highlights the studies of Marcuse, such as "Eros and Civilization" and "One-Dimensional Man: Studies in the Ideology of Advanced Industrial Society", which pointed to narcissism as inherent to the way society was organized, allowing the free flow of desires. These studies demonstrated that the transformations occurring in society acted upon the family, the place of primordial identifications, and included changes in education and work schedules, which changed peoples' ways of life. The dramatizations of affects, love and hate, which in theory would 
produce a stable Self, extended to a variety of identification models that, on the contrary, fragmented it. This made the Self fragile and implied a hypersensitivity susceptible to maximizing the perception of danger in everyday life situations.

There is an important political implication to this finding. For Lasch, the intensification of individualism is one critical effect of the culture of narcissism. Most survival measures leave the public space and migrate to the private sphere, where protection becomes an object of individual consumption.

Crochík (1990) reinforces this phenomenon, highlighting technological rationality as responsible for the depoliticization of the masses during this period. This rationality would reveal the assumptions of neutrality and advancement afforded by technique - a principle that the more technical political decisions were, the more perfected society would be (CROCHÍK, 1990, p. 153). This modus operandi would also be seen in administration, in which management competence is estableshid by techniques that are proposed through the same self-reproducing normative parameters, while shaping experts who hold the legitimacy to pronounce technical truths.

It is important to emphasize that the individual-society interaction, analysed by these authors in the post-war context, is marked by discourse about the threat of mass destruction, created an "awareness of the end of the world" (HOBSBAWN, 2004, p. 224). This awareness reached everyday life, as Lasch (1983) shows. The subject in this society became the subject of risk. Risk became the cultural sign that guides survival; it became what the subject must address in order to gauge its conduct and orient its practices toward behaviors that allow it to avoid encountering finitude.

\section{Risk and death}

The survival mentality is constituted in a sociocultural context in which security and risk assume an important place. It is about this same context that the German sociologist Ulrick Beck seeks to develop his social theory of risk, particularly with his work Risk Society, originally published in German in 1986, in which he discusses the transformations that this new reality was producing. It is possible to understand Beck's theory linked to the interpretation of the culture of narcissism: an age of diminishing expectations (LASCH, 1983) is, for Beck, an age of uncertainty (Beck, 2010).

Beck describes risk society as the social organization that arises in a moment of transition, in which the material and spiritual production of life distances itself from the categories of industrial society. These changes are described in his analysis of the capitallabor relation, of family structure, gender issues, biographical transformations, and migratory geography. In these spheres the author observes a deepening of individualism, at the same time that he notes a standardization of ways of life, placing the individual and its behaviors as a "plaything of fashions, circumstances, trends and markets" (BECK, 2010, p. 194). However, the central point in his theory is the elevation of risk as a sociological category (MOTTA, 2014).

The risks that today's society is dealing with differ from the risks of industrial 
society, in which there prevailed an insurance culture, subjectable to quantification and calculation in order to guide action. Risks, for Beck, no longer include this possibility of calculation: they escape the logic of industrial society and cannot be apprehended by it. Their scope has expanded in time and space, becoming global, intergenerational and without borders. In addition, there is a disconnection between the production of risk and those who are responsible for its production, since the very logic in which risk is produced makes those responsible invisible and makes accountability unfeasible (BECK, 2006; GIDDENS, 1995).

In the face of global risks, the theme of survival, and therefore of narcissism, gains a global dimension (BECK, 1999), for the fear of death in this society is planetary death. It is the finitude of the planet that is at stake: "as a species, we no longer have a guaranteed survival” (BECK; GIDDENS; LASH, 1995, p. 9).

This social organization that produces risks and uncertainties, and whose invisibility makes it difficult to establish the cause and effect relationships associated with them, places individuals in a permanent condition of indeterminacy. These global risks are not easily available to sensoriality, neither immediately noticed, but they depend on a discourse that makes them visible and intelligible - a process in which science is mobilized to offer the symbolization necessary for their treatment (BOSCO, 2011). It is the discourse of technoscience that will mediate this abandoned subject to himself, facing risks of incalculable consequences.

These changes reveal the failure of the instrumental rationality with which all of the scientific architecture based on the control of risks, nature and instruments was built (BRITO; RIBEIRO, 2003). If, in industrial society, risk could still be predicted and assumed as a calculation of insurance (MELLO; ACSELRAD, 2002), in risk society, it is considered a side effect of the control process: it is the uncontrollable remainder of the practice of control, the incalculable effect of the practice of calculation. However, indeterminacy demands determination, and the attempt to respond, as Beck argues, intersects with his concept of reflexivity.

\section{Reflexivity: the mirror of the global Narcissus}

Beck distinguishes two modernities and does so chronologically, which has been subject to some critiques for propounding an evolutionary vision of society (COSTA, 2004) and for centering analysis on European society (MOTTA, 2014). For this article, it is important to highlight certain aspects of these two moments. The first of them is what he calls simple modernity, characterized by the industrial process in which the production of wealth and risk is under the control of the rationality being employed. The second refers to a radicalization of this process, in which risks, once unleashed, create the impression of a world "out of control" (BOSCO; DI GIULIO, 2015, p. 149). This difficulty has been incorporated in discourses and has impacted at the institutional level (BECK, 1995). Beck called as reflexive modernity the moment which is characterized by the production of wealth whose surpluses produce unpredictable risks, requiring new solutions. Reflexivity lies in the treatment of this surplus: risks are the reflex of produc- 
tion, called manufactured or self-produced risks.

Beck warns that it was the success of the industrial model that generated the risks that science must address, either to avoid them or to overcome them. These risks bring about unprecedented situations which are, in general, of a global magnitude. They involve matters of survival that cannot be the sole responsibility of science, represented by specialists (KASPERSON et al., 1988), but that should be dealt with in the political field (PIELKE, 2004; YEARLEY, 1992) by the various groups affected (CALLON, 2009). Thus, politics must also be called upon to deal with its image in the mirror, in order to reorient values and strategies and reorganize power and responsibility (BECK, 2010; GIDDENS, 1995, 1999).

"'Reflexive modernization' means self-confrontation with the effects of risk society that cannot be dealt with and assimilated in the system of industrial society" (BECK, 1995, p. 18). Risks now become the object of technoscientific reflexivity, since science needs to deal with itself, that is, with the effects of its own application (BECK, 2010). Science would, therefore, be dealing with its excessive image - since, due to its success, it must turn to its own rationality to face the problems it generated. This process of dealing with its image in the mirror to repair the side effects of its productivity leads to a repetition compulsion (FREUD, 2006e; GIDDENS, 1995) of the event that caused the problem. The side effect is part of the process, yet it is recognized as its exteriority and, in turn, becomes a demand for more technoscience (BECK, 2010). The logic refounds itself indefinitely, as it is guided by the technically correct decision (CROCHIK, 1990).

If Lasch's analysis frames survival as a societal matter, Beck's goes further by stating that "risk society is a catastrophic society" (BECK, 2010, p. 28). However, both highlight an intensification of individualism and with it an indeterminacy that, in Beck's work, also appears as a search for lost security (BECK, 2006; IANNI, 2012). Risk conflicts are linked to the security/insecurity relation, prompting the return of uncertainty (BECK, 1995). They differ from the problems of order in industrial society, which are ambivalent toward the possibility of calculating probability and its resolving power. With technological advancement, science is able to produce increasingly accurate diagnoses and definitions about planetary finitude, but it becomes powerless to solve the problems of this finitude except by transforming the ways of life that demand more technology and efficiency. This is the logic of the threat in which, in order to defend from finitude/crisis/catastrophe/ scarcity, the subject must adapt its behavior and its relations.

It is in this reflexive process that sustainable development is situated. As a conceptual arrangement based in a technoscientific diagnosis of future catastrophe, the proposed sustainable development prescribes another way of life in order to prevent the environmental crisis and climate change from reaching a point of no return. Since the Brundtland Report, a series of changes in different spheres of life have been proposed in response to the threats to survival. Their emphasis, however, is on the global political-economic arena which proposes, through the institutionalization of sustainable development, a way of life capable of reconciling a new era of economic growth with the protection of finite resources, made possible by technological innovations (CMMAD, 1987). It is precisely 
at this conjuncture that we may understand the narcissistic ideal of wholeness in this instituting discourse.

The Brundtland Report seeks to avoid the future catastrophe mediated through future technology, exemplifying what Beck positions as a reflexive society: "that it becomes a theme and a problem for itself" (BECK, 1995, p. 22). It is in this perspective that we propose that sustainable development may be understood as a narcissistic strategy. This discursive arrangement is put forward as a symbolic support to the protective measures, social practices and transformations that are desired to achieve the ideal way of life. However, as we will show in the next section, the statements about sustainable conduct to avoid global death, as formulated in the report Our Common Future, may be understood as a form of omnipotent fantasy.

\section{Sustainable development as a narcissistic strategy}

Sustainable development may be conceived as a political strategy and, therefore, is within the social process in which values function as identification models that aim to ensure intergenerational and planetary survival (CMMAD, 1987; CNUMAD, 1992). As a narcissistic survival strategy, sustainable development attempts to avoid finitude at the global scale through transformations of human practices, including technoscientific developments to reverse or minimize environmental losses. It emerges in a context inherited from the survivalist logic of the first decades of the post-war period and thereby develops within a culture of narcissism. Thus, sustainable development is presented as a new paradigm for coping with the environmental crisis - or existential crisis, as we argue. This paradigm retains a component of finitude, since it is not possible to know its extension in time and space, and should be taken as a new condition of existence.

The perception of the prevailing way of life's harmful consequences to the environment is constituted in the context of this logic of global survival, initially understood as a culture of narcissism, particularly from the 1960s onwards. The environment, mediated by science, becomes both an object of fear and an object to be protected. The division between fear and protection is reflected in risk society and is marked by forms of nonknowledge, commonly referred to as uncertainty, insecurity and indeterminacy.

As the Brundtland Report maintains with regard to environmental degradation, humanity would have exceeded the thresholds that allow life to be sustained as it is known (CMMAD, 1987). This gives rise to a perspective of future tragedy that, to be avoided, requires changes in the lifestyle of humanity as a whole. As shown in the document, the decades that followed the Second World War were ones of "drastic growth and fundamental changes" (CMMAD, 1987, p. 5), with an increase in the world population in the context of finite resources, subsoil impacts from agricultural exploitation, accelerated urbanization, consumer culture and other effects of the development of industrial society.

It is worth noting that in the post-war period nature itself became inscribed as a social problem (HANNIGAN, 2006; LASCH, 1986; BECK, 1995), since there is no longer any nature that has not been affected by human intervention (GIDDENS, 1999). It is at this moment that degradation, related to the industrial way of life, comes to be 
seen as a matter of life and death (LASCH, 1986). The idea of finitude thus takes on the face of a global environmental threat. The environmental crisis exposes this disturbance in the form of thresholds, which have become the object of reflexive science and have put demands on the political process, now seen as the means by which existence must be made possible. However, as the authors mentioned in this article argue, this process has gained another connotation insofar as it is influenced by the technical logic that, when defining risks, also defines the margin of negotiation for the solutions. This displaces the site of conflict, which comes to be directed by the reflexivity of technique in the form of risk conflicts.

When analyzing the discourse of global environmental threat - that is, of disturbance in the form of thresholds - it is necessary to keep in mind that, in the psychoanalytical approach, discourse is the way of ordering the very social bonds that produce the subject, because the formations of the unconscious are "[...] tributaries of the structure of this collective, public and symbolic organ" (KHEL, 2009, p. 25-26). Discourse is the apparatus that creates social bonds, considering that there is no world that is not subjectable to representation and that language is the site of the subject and the means by which it establishes social relations. The effects of the discourse are real effects, since it is through discourse that the subject's world is structured.

In this understanding, sustainable development is part of a formation that, according to Silva Júnior (2017), must be understood by its technical grammar, that is, as a symbolic structure in which social bonds are ordered. This author's interpretation can provide a psychoanalytic complement to Beck's reading of reflexivity and the presence of survival in the discursive constructions of sustainable development. Drawing on Heidegger's notes on the question of technique, Silva Júnior described technical grammar as this form of "totalitarian and totalizing" symbolic structuring that became a "metaphysical system" (SILVA JÚNIOR, 2017, p. 178). Technical grammar is reflected in a structure that stops conceiving of its own foundations (LEBRUM, 2001) so as to promote an instrumental form of thought, understood as a refusal of finitude that is not only the individual beingfor-death, but that "impregnates the order of culture as a whole" (SILVA JÚNIOR, 2017, p. 178).

This refusal of finitude present in the social bond exposes a process that, in the face of its own threshold, makes use of technique as a means for denial, sustaining the belief in its own immortality. The reflexivity described by Beck is the way in which society would organize itself to deal with the unbearability (discontent) provoked by planetary finitude, which is seen only through technical grammar. In other words, facing the possibility of finitude, the narcissistic measure of denial is socially processed in the form of technoscientific omnipotence.

This narcissistic aspect - omnipotence - can be seen in the narratives that underlie the totalizing forms in which sustainable development is presented: existence only becomes possible as long as it respects sustainable parameters. This operating logic treats global narcissistic omnipotence as a symptom of impotence (fragility) in the face of the techno-scientific assessment of a crisis that announces planetary death, whose emissaries 
take the form of technically defined risks (BECK, 2010).

Structured in technical grammar, the ordering discourse of society, sustainable development functions as a symbolic structure that orients subjectivity and social practices. It therefore becomes, on the one hand, a strategy for preserving existence and, on the other, a field in which political disputes must come to pass and in which human conduct is shaped into different lifestyles (CASTIEL; DIAZ, 2007), represented by ways of living that sustain the belief that the worst can be avoided with adequate conduct.

As a field of conflict, its application creates side effects (BECK, 2010), leading to the proliferation of reflexive practices that aim to reduce the feeling of insecurity/uncertainty. The production of insecurity, in turn, demands increasingly sophisticated technical control, which generates an uncontrollable/incalculable/insecure residue, as Beck (2010) points out. This residue demands more control, revealing what the narcissist tries to hide with omnipotence - its impotence in dealing with finitude. This insecurity-control dialectic is the social expression, in technical-reflexive grammar, of this impotence-omnipotence relationship that characterizes the narcissistic defense as the reflex of a new social configuration - a society of global risks, in which new forms of psychic suffering are manifested.

For Lebrun (2001), this complex process involves an absence proper to technoscientific discourse, since its ordering does not permit the inscription of the impossible. This non-inscription, this inconceivable, is the gateway to the feeling of helplessness (insecurity/uncertainty) and to its symbolic coating through fantasies of omnipotence (and of technical constructions such as technological innovations). In this author's perspective, this is the metapsychological foundation of the construction of the contemporary social bond, which places ontological insecurity at the center of the current way of life. This insecurity is a symptom of this social time, characterized by a state of affairs linked to a set of social transformations that place risks at the heart of the social process. As a result, the contemporary society constantly needs to deal with its own deadly potential and with the risk of death on a global scale that permeates human and non-human processes alike - social, psychological and environmental.

\section{Subjective effects of the sustainable development discourse}

Sustainable development has become the planetary strategy that assumes the refusal of finitude. It deals, therefore, with a set of prescriptions for States, non-governmental organizations and people in general (CMMAD, 1987) on how to be and act in order to guarantee the intergenerational immortality of a way of life incapable of renouncing unlimited growth.

Its grammar is anchored in efficiency and future-oriented knowledge, allowing technological innovations in line with economic growth to proliferate. We argue that sustainable development seeks to deny the subjective inscription of the impossible through the technical introduction of new artifacts, reinforcing the belief in the technical and reflexive management of global risks. This type of social bond that fears finitude precludes the renunciation of narcissistic omnipotence, because the language by which the bond is structured sustains the belief in unlimited possibility. Its language only conceives of this 
omnipotence as a way to avoid finitude through its own constructions, preserving the possibility of wholeness through rational calculation - via improvement, technoscientific performance, efficiency and innovation.

The effect of sustainable development discourse, therefore, is an imperative sustained by a belief in the unlimited, justifying the acceleration of the productive process by making it more adjusted to deal with threats. Subjectively, efficiency becomes imperative to behaviors conceived under the metric of maximization. The impulse toward acceleration is identified with and reproduced by fragile subjects who are driven by fear (BECK, 2010) and linked through the narcissistic social bond. This impulse is inscribed in the quest to extract a plus (representative of narcissistic wholeness), which ultimately enters every sphere of social participation that promises to make individual action more efficient. Maximization, acceleration, innovation, optimization and efficiency are part of a significant series of security indexes that desire the subject under the threat of death. These are the ideals to be realized to avoid encountering finitude. In this way, practices are articulated by the discourse to avert global risks.

The imperative for efficiency and performance is the social value of the technical grammar that, in the institutional field, uses the environment to justify the means necessary to reduce the effects of planetary resource depletion and avoid future suffering. In practice, however, it reinforces a way of life that ultimately exhausts humans themselves, whose discontent will also manifest in the form of individual illness. It thus lays the foundations of environmental and human exhaustion (ARAUJO, 2019).

This may be one of the reasons for the contemporary epidemics of depression (EREHNBERG, 2010) and burnout (HAN, 2016), a chronic stress syndrome linked to the occupational field (PAHO, 2019). These epidemics show the paradox of the omnipotence/ impotence relationship that regulates conduct.

This process occurs because the grammar in which the discourse of sustainable development is produced to cope with the environmental crisis is the same grammar that orients the contemporary subject. It is a discourse that works to increase productivity by extracting efficiency, very similar to what is recommended in Brundtland (CMMAD, 1987). This discourse was also identified by Dardot and Laval (2016) in their work on neoliberal society. The authors call this process the new way of the world, a normative global logic that not only destroys but also "produces certain types of social relationships, certain ways of living, certain subjectivities" (DARDOT; LAVAL, 2016, p. 16).

In this context, the subject is caught between the management of growth and the management of risks in order to be sustainable within technical parameters. The search for totalization sustains the experience of indeterminacy, in which the eternal satisfaction of future generations' needs becomes both a social imperative and a social ideal, putting nations, companies and people (CMMAD, 1987) to work in an arduous regime of efficiency extraction. This social ideal is at the heart of forms of overload, increasing production at the cost of exhaustion without acting to reduce insecurity and uncertainty about future scarcity. In this sense, narratives about risks and losses circulate to mobilize affects of horror toward finitude, placing the subject in a state of helplessness before the 
uncertainties that proliferate (BECK, 2010), thereby resetting reflexive repetition.

\section{Final considerations}

In a world characterized by invisible risks, the discourse that promises protection will have narcissistic value to the helpless subject. Sustainable development and its technical grammar reproduce narcissistic omnipotence which, according to psychoanalysis, may be broken by the reality principle, that is, by the imposition of reality over omnipotence. This process inscribes the impossibility of avoiding finitude.

It is possible to argue that the environmental crisis must function as a reality principle capable of exerting this effect, because the process of desertification, climate change, the reduction of biodiversity, the continued emission of greenhouse gases (GHG), and the countdown to the last drop of water are some indicators of a series of environmental problems that demonstrate the truth of finitude. The political-economic resistance to accepting finitude as a possibility is an indicator of the strength of the (narcissistic) omnipotence that structures contemporary technical society, since no innovation or creation is capable of achieving unlimited economic growth with environmental protection; humans are incapable of that.

The discontents contemplated by Freud allowed him to express the social conflict between pleasure and security, in which the choice of security inevitably implied the renunciation of pleasure (FREUD, 2006f). In reflexive modernity the mechanism is different; the return to oneself indefinitely is not only mediated by the search for security through technoscientific development, but also by the preservation of the belief in unlimited economic growth, an omnipotent belief that must be broken by the reality of crisis.

As a political strategy, sustainable development takes an important step towards this breaking point by shedding light on this reality in a global political arena. However, sustainable development has not disrupted this belief by transforming the discourse of unlimited economic growth that sustains the current economic model. The reflexive stage of cultural discontent may perhaps be theorized in view of the conflict that sustainable development makes increasingly explicit. Its political therapeutics (SILVA JÚNIOR, 2017) involve no longer treating impotence with technical omnipotence and recognizing this impotence as a real impossibility for the proliferation of possibilities, such as some economic theories whose narratives diverge from the neoclassical tradition and look at survival from a point of entropy (VEIGA, 2019).

The recognition of impossibility must be incorporated into the structure of symbolic and material exchange because the denial of the impossible, reflexively revolving around itself, has created a compulsion toward technological innovation that sustains the belief in unlimited economic growth. This process only causes global risks and insecurity to proliferate; it does not protect the planet from collapse and lays the foundation for human exhaustion. 


\section{References}

ARAUJO, A.K. Mal-Estar na Sociedade de Risco: um debate interdisciplinar sobre sustentabilidade. Tese de Doutorado. Saúde Global e Sustentabilidade, USP. 2019.

BECK, U. A reinvenção da política: rumo a uma teoria da modernidade reflexiva. In: BECK, U.; GIDDENS, A.; LASH, S. Modernização reflexiva: política, tradição e estética na ordem social moderna. Tradução de Magda Lopes. São Paulo: Universidade Estadual Paulista, 1995.

BECK, U. La sociedad del riesgo global. Madrid: Siglo XXI España Editores, 2002.

BECK, U. Living in the world risk society. Economy and Society. London, v. 35, n. 3, Aug. p. 329-345, 2006.

BECK, U. O que é Globalização? equívocos do globalismo: respostas a globalização. São Paulo: Paz e Terra, 1999.

BECK, U. Sociedade de risco: rumo a uma outra modernidade. Tradução de Sebastião Nascimento. São Paulo: Editora 34, 2010.

BECK, U.; GIDDENS, A.; LASH, S. Modernização reflexiva: política, tradição e estética na ordem social moderna. Tradução de Magda Lopes. São Paulo: Universidade Estadual Paulista, 1995.

BOSCO, E. M. G. R. Ulrich Beck: a teoria da sociedade de risco mundial. 2011. 181 p. Dissertação (mestrado) - UNICAMP, Campinas, 2011.

BOSCO, E.M.; DI GIULIO, G.M. Ulrichbeck: considerações sobre sua contribuição para os estudos em ambiente e sociedade e desafios. Ambient. soc. São Paulo, v. 18, n. 2, p. 149-160, abr/ jun. 2015.

BRITO, D. C; RIBEIRO, T. G. A modernização na era das incertezas: crise e desafios da teoria social. Ambient.soc., Campinas, v. 5, n. 2, p. 147-164, ago./dez. 2003.

CALLON, M. Acting in an uncertain world: an essay on technical democracy. Massachussetts, London: MIT Press, 2009.

CANEVACCI, M. Quatro Mitos Para Um Narciso “Só”. IDE. São Paulo, v. 21, p. 92-101, 1991.

CASTIEL, L. D.; DIAZ, C. A-D. Saúde Persecutória: os limites da responsabilidade. Rio de Janeiro: Fiocruz, 2007. 136 p.

CMMAD - Comissão Mundial de Meio Ambiente e Desenvolvimento. Nosso futuro comum. Rio de Janeiro, Editora da Fundação Getúlio Vargas, 1987.

CNUMAD - Conferência Das Nações Unidas Sobre Meio Ambiente E Desenvolvimento. São Paulo: Secretaria de Estado do Meio Ambiente, 1992. 
COSTA. S. Quase crítica: insuficiências da sociologia da modernização reflexiva. Tempo Soc., São Paulo, v. 16, n. 2, p. 73-100. Nov. 2004.

COSTA, A.; POLI, M. C. Alguns fundamentos da entrevista na pesquisa em psicanálise. Pulsional: Revista de Psicanálise. São Paulo, v. 19, n. 188, p. 14-21, 2006.

COSTA, J. F. Violência e Psicanálise. Rio de Janeiro: Graal. 2003.

CRISTÓFARO, H. et al. Narcisismo: identidade e diferença - uma unidade em tensão? In: SAFATE, V., SILVA JUNIOR, N. e DUNKER, C. (Org.). Patologias do social: arqueologias do sofrimento psíquico. Belo Horizonte: Autêntica, 2018.

CROCHIK, J. L. A personalidade narcisista segundo a Escola de Frankfurt e a ideologia da racionalidade tecnológica. Psicol. USP, São Paulo, v. 1, n. 2, p. 141-154, dez. 1990.

DARDOT, P. LAVAL, C. A nova razão do mundo: ensaio sobre a sociedade neoliberal. São Paulo: Boitempo. 2016.

DODDS, J. Psychoanalysis and ecology at the edge of chaos: Complexity theory, Deleuze, Guattari and psychoanalysis for a climate in crisis. Routledge, 2012.

DRUMMOND, J.A. A primazia dos cientistas naturais na construção da agenda ambiental contemporânea. Rev. bras. Ci. Soc., São Paulo, v. 21, n. 62, p. 5-25, Oct. 2006.

DRYZEK, J. The politics of the earth. Oxford, Oxford University Press. 2005.

DUNKER, C. etal.Análise psicanalítica de discursos: perspectivas lacanianas. São Paulo: Estação das letras, 2016.

DUNKER, C. et al. Romance policial e a pesquisa em psicanálise. Interações, São Paulo, v. 7, n. 13, p. 113-126, jun. 2002.

EHRENBERG, A. O culto da performance: da aventura empreendedora à depressão nervosa. Aparecida: Idéias e Letras. 2010.

FERREIRA, L. A Centralidade da Interdisciplinaridade nos Estudos Sobre Ambiente e Sociedade. Política e Soceidade, v. 4, n. 7, p. 185-201, 2005.

FREUD, S. Além do princípio do prazer. Edição Standard Brasileira das Obras Psicológicas Completas de Sigmund Freud. Rio de Janeiro: Imago, 2006e. v. XVIII.

FREUD, S. Conferências introdutórias sobre Psicanálise (Parte III). Edição Standard Brasileira das Obras Psicológicas Completas de Sigmund Freud. Rio de Janeiro: Imago, 2006a.v. XVI.

FREUD, S. Construções em Análise. Edição Standard Brasileira das Obras Psicológicas Completas de Sigmund Freud. Rio de Janeiro: Imago, 2006c. v. XXIII.

FREUD, S. Dois verbetes de enciclopédia. Edição Standard Brasileira das Obras Psicológicas 
Completas de Sigmund Freud. Rio de Janeiro: Imago, 2006b. v. XVIII.

FREUD, S. Mal-estar na Civilização. Edição Standard Brasileira das Obras Psicológicas Completas de Sigmund Freud. Rio de Janeiro: Imago, 2006f. v. XXI.

FREUD, S. Sobre o Narcisismo: uma Introdução. Edição Standard Brasileira das Obras Psicológicas Completas de Sigmund Freud. Rio de Janeiro: Imago, 2006d. v. XIV.

GIDDENS, A. A Vida em uma Sociedade Pós-tradicional. In: BECK, U.; GIDDENS, A.; LASH, S. Modernização reflexiva: política, tradição e estética na ordem social moderna. Tradução: Magda Lopes. São Paulo: Universidade Estadual Paulista, 1995.

GIDDENS, A. RiskandResponsibility. The Modern Law Review. Limited. London, v. 62, p. 1-10, Jan. 1999.

HAN, B-C. Sociedade do cansaço. Petrópolis: Vozes, 2016.

HANNIGAN, J. Sociologia Ambiental. Petrópolis: Vozes, 2006.

HERCUlANO, S. Do Desenvolvimento (In)Suportável à Sociedade Feliz. In: Goldenberg, M. (org.). Ecologia, Ciência e Política. Rio de Janeiro: Revan, 1992, pp. 9 - 48.

HOBSBAWN, E. Era dos Extremos: o breve século XX 1914-1991. 2a edição, São Paulo: Companhia das Letras, 2004.

IANNI, A. M. Z. Choque antropológico e o sujeito contemporâneo. Ulrich Beck entre a ecologia, a sociologia e a política. Sociologias. Porto Alegre, v. 14, n.30, p. 364-380, Mai./Ago. 2012.

IRIBARRY, I. N. O que é pesquisa psicanalítica? Ágora, v. VI n. 1, p. 115-138, Jan./Jun. 2003.

KASPERSON, R. E., RENN, O., SLOVIC, P., BROWN, H. S., EMEL, J., GOBLE, R., KASPERSON, J. X. and RATICK, S. The Social Amplification of Risk: a conceptual framework. RiskAnalysis, v. 8, i. 2, p. 177-187, Jun. 1988.

KEHL, M. R. O Tempo e o Cão: a atualidade das depressões. São Paulo: Boitempo, 2009.

LAGO, C. AMARAL, F. B. MÜHL, C. Reflexões acerca da crise ambiental e a condição humana. Rev. Eletrônica Mestr. Educ. Ambient., v. 30, n. 1, p. 159 - 178, Jan./jun. 2013.

LASCH, C. A cultura do Narcisismo: a vida americana numa era de esperanças em declínio. Rio de Janeiro: Imago, 1983.

LASCH, C. O Mínimo Eu: sobrevivência psíquica em tempos difíceis. Brasiliense. São Paulo: 1986.

LEBRUN, J-P. Um mundo sem limite: ensaio para uma clínica psicanalítica do social. Rio de Janeiro: Companhia de Freud, 2001. 
MELLO, C. C. A. \& ACSELRAD, H. Conflito social e risco ambiental: o caso de um vazamento de óleo na Baía de Guanabara. In: ALIMONDA, H. Ecología política: naturaleza, sociedad y utopía. Buenos Aires, 2002.

MOTTA, R. Risco e Modernidade Uma nova teoria social? Rev. bras. Ci. Soc. São Paulo, v. 29, n. 86, Out. 2014.

NASCIMENTO, E. P. Trajetória da sustentabilidade: do ambiental ao social, do social ao econômico. Estud. av., São Paulo, v. 26, n. 74, p. 51-64, 2012.

NASIO, J.D. Lições sobre os sete conceitos cruciais em psicanálise. Rio de Janeiro: Jorge Zahar Ed., 1997.

OPAS. Organização pan americana da saúde. Brasil, 2019. Disponível em: https://www.paho. org/bra/index.php? option $=$ com_content $\&$ view $=$ article $\& i d=5949:$ cidburnout $-\mathrm{e}-\mathrm{um}$-fenomenoocupacional\&Itemid = 875\#: :text $=$ CID\%3A\%20burnout $\% 20 \%$ C3\%A9\%20um\%20 fen\% C3\%B4meno\%20ocupacional,como\%20uma\%20condi\%C3\%A7\%C3\%A3o\%20de\%20 sa\%C3\%BAde. Acesso em: 21 Jun. 2020.

ORGANIZAÇÃO DAS NAÇÕES UNIDAS. Declaração do Milênio. Cimeiro do Milênio. Nova Iorque, 6-8 set. 2000.

ORGANIZAÇÃO DAS NAÇÕES UNIDAS. Healthy Planet Healthy People.Sixth Global Environment Outlook assessment report. Cambridge University Press. 2019.

ORGANIZAÇÃO DAS NAÇÕES UNIDADES. Relatório sobre os Objetivos de Desenvolvimento do Milénio. New York: ONU. 2015.

PIELKE JR, R. When scientists politicize Science: making sense of controversy over the sceptical environmentalist. Environmental Science \& Policy. v. 7, i. 5, p. 405-417, 2004.

RANDALL, R. Loss and climate change: The cost of parallel narratives. Ecopsychology, v. 1, n. 3, p. $118-129,2009$.

ROCKSTRÖM, J. et al. A safe operating space for humanity. Nature, v. 461. n. 24. September. 2009.

ROSA, M. D. A pesquisa psicanalítica dos fenômenos sociais e políticos: metodologia e fundamentação teórica. Mal-Estar e Subjetividade. Fortaleza. v. IV, n. 2, p. 329 - 348. Set. 2004.

ROSA, M. D.; DOMINGUES, E. O método na pesquisa psicanalítica de fenômenos sociais e políticos: a utilização da entrevista e da observação. Psicologia e Sociedade, v. 22, n. 1, p. 180. 188. 2010.

SAFATLE, V. Em direção a um novo modelo de crítica: as possibilidades de recuperação contemporânea. In: SAFATE, V., SILVA JUNIOR, N. e DUNKER, C. (Org.). Patologias do social: arqueologias do sofrimento psíquico. Belo Horizonte: Autêntica, 2018. 
SEARLES, H. F. Unconscious processes in relation to environment crisis. Psychoanalytical Review, v. 59, n. 3, p. 361-374. 1972.

SILVA JUNIOR, N. Um ponto cego de O Mal-estar na Cultura: a Ciência na era da Instalação. Estud. av., São Paulo, v. 31, n. 91, p. 173-192, Dec. 2017.

SILVA JUNIOR, R. D., FERREIRA, L. C., LEWINSOHN, T. M. Entre hibridismos e polissemias: para uma análise sociológica das sustentabilidades. Ambient. soc. São Paulo, v. 18, n. 4, p. 35-54, Dec. 2015.

SWYNGEDOUW, E. ApocalypseForever? Theory, Culture $\&$ Society, v. 27, n. 2-3, p. 213232. 2010.

VEIGA, J. E. O Antropoceno e a Ciência do Sistema Terra. São Paulo: Editora 34, 2019.

WEINTROBE, S. Engaging with climate change: Psychoanalytic and interdisciplinary perspectives. Routledge, 2013.

YEARLEY, S. Green Ambivalence about Science: legal-rational authority and the scientific legitimation of social movement. The british journal of sociology, v. 43, n. 4, p. 511-532, Dec. 1992. 
Adriano Kasiorowski de Araujo

๑adrianokaraujo@gmail.com

ORCiD: https://orcid.org/0000-0002-2387-2472
Submitted on: 16/05/2019

Accepted on: 09/08/2020

2020;23:e00503

\section{Gabriela Marques Di Giulio}

घgiulio@usp.br

ORCiD: https://orcid.org/0000-0003-1396-9788

How to cite: ARAUJO, A. K.; DI GUILIO, G. M. Sustainable development: a narcissistic strategy to cope with the environmental crisis. Ambiente $\mathbb{\&}$ Sociedade. São Paulo, v. 23, p. 1-19, 2020. 


\title{
Desenvolvimento sustentável: uma estratégia narcísica para enfrentar a crise ambiental?
}

\author{
Adriano Kasiorowski de Araujo \\ Gabriela Marques Di Giulio
}

São Paulo. Vol. 23, 2020

Artigo Original
Resumo: Este artigo analisa a institucionalização do discurso do desenvolvimento sustentável (DS) há mais de três décadas e seus desdobramentos enquanto articulação simbólica que agencia a subjetividade e práticas sociais neste século. Contemplando uma abordagem interdisciplinar, concentra-se em um debate entre a psicanálise, atenta às formas de manifestação do mal-estar, e às ideias de sociedade de risco e modernização reflexiva, da teoria social do risco. A análise do discurso sobre DS permite enquadrá-lo enquanto estratégia narcísica de enfrentamento da crise ambiental. Tal estratégia estrutura-se namanutenção da existência, ao mesmo tempo que coloca em disputa um processo constante de definição sobre qual modo de vida as populações devem viver e como as condutas humanas devem se guiar. Com um discurso de negação da finitude, apoiado na necessidade de eficiência e desenvolvimento tecnológico para evitar o fim dos recursos, essa estratégia narcísica pode, em última instância, deixar lastros de esgotamento ambiental e humano.

Palavras-chave: Narcisismo, sobrevivência, risco, reflexividade, desenvolvimento sustentável.

Como citar: ARAUJO, A.K.; DI GIULIO, G.M. Desenvolvimento sustentável: uma estratégia narcísica para enfrentar a crise ambiental?. Ambiente \& Sociedade. São Paulo, v. 23, p. 1-19, 2020.

DOI: http://dx.doi.org/10.1590/1809-4422asoc20190050r3vu2020L6AO 


\title{
Desarrollo sostenible: ¿una estrategia narcisista para enfrentar la crisis ambiental?
}

\author{
Adriano Kasiorowski de Araujo \\ Gabriela Marques Di Giulio
}

São Paulo. Vol. 23, 2020

Artículo original
Resumen: Este artículo analiza la institucionalización del discurso del desarrollo sostenible (DS) durante más de tres décadas y su desarrollo como una articulación simbólica que influye en la subjetividad y las prácticas sociales en este siglo. Al contemplar un enfoque interdisciplinario, se centra en un debate entre el psicoanálisis, atento a las formas de manifestación del malestar, y a las ideas de la sociedad del riesgo y la modernización reflexiva, de la teoría del riesgo social. El análisis del discurso de DS permite enmarcarlo como una estrategia narcisista para enfrentar la crisis ambiental. Dicha estrategia se estructura en el mantenimiento de la existencia, al mismo tiempo que pone en disputa un proceso constante de definición sobre qué forma de vida deben vivir las poblaciones y cómo se debe guiar la conducta humana. Con un discurso técnico de negación de finitud, respaldado por la necesidad de eficiencia y desarrollo tecnológico para evitar el fin de los recursos, esta estrategia narcisista puede, al final, dejar atrás lastres de agotamiento humano y ambiental.

Palabras-clave: Narcisismo, supervivencia, riesgo, reflexividad, desarrollosostenible.

Como citar: ARAUJO, A. K.; DI GUILIO, G. M. Desarrollo sostenible: ¿una estrategia narcisista para enfrentar la crisis ambiental? Ambiente \& Sociedade. São Paulo, v. 23, p. 1-19, 2020.

DOI: http://dx.doi.org/10.1590/1809-4422asoc20190050r3vu2020L6AO 
